\title{
Symptoms of vibration syndrome and radiographic findings in the wrists of lumberjacks
}

\author{
H HÄRKÖNEN, ' HILKKA RIIHIMÄKI, ${ }^{2}$ S TOLA, ${ }^{1}$ T MATTSSON, ${ }^{1}$ M PEKKARINEN, 1 \\ A ZITTING,' AND K HUSMAN'
}

From the Institute of Occupational Health' and the Employment Pension Fund, ${ }^{2}$ Helsinki, Finland

ABSTRACT In a cross sectional study 279 lumberjacks exposed to chain saw vibration and a reference group of 178 peat bog workers were examined. The mean ages of the two groups were 34.6 and 33.1 years, respectively. The lumberjacks' mean duration of exposure to vibration was 10.4 years. The study consisted of a questionnaire and a clinical examination, including radiographs of the wrists. The prevalence of reported white finger symptoms was $18 \%$ for the lumberjacks and $3 \%$ for the referents, whereas that of numbness in the upper extremities was $51 \%$ and $22 \%$, respectively. Among lumberjacks the occurrence of white finger symptoms increased significantly with the duration of exposure to vibration but was not associated with age or smoking. The prevalence of the numbing of the upper extremities increased linearly with age in both groups, but it was not associated with duration of exposure after adjustment for age. Among lumberjacks there was a significant association between the numbing symptom and the white finger symptom, but not among the referents. A high prevalence of numbing in the upper extremities among the lumberjacks could be at least partly explained by occupational factors other than vibration-work posture, for example. Radiographically, cysts were found in the wrist bones of 8-9\% of both groups. The exposure to chain saw vibration no longer seems to be a determinant in the development of vacuoles in the carpal bones.

Chain saw vibration can give rise to a set of symptoms called the vibration syndrome. The symptoms may occur simultaneously or separately and include paroxysmal ischaemia provoked by cold in the fingers, so called traumatic vasospastic disease or vibration induced white finger. Numbing of the hands and arms, muscular fatigue, and degenerative bone changes are also considered to be signs of the vibration syndrome. $^{1}$

Although bone changes, such as vacuoles and necrosis of the lunate or navicular bones, have been associated with exposure to vibration, ${ }^{2-4}$ these findings have not been consistent in all studies. ${ }^{56}$ In addition, numbness of the hands and arms in connection with vibration exposure is often present during the night, ${ }^{1}$ but few studies have reported the prevalence of this symptom in non-exposed populations. ${ }^{78}$ The present study was undertaken to evaluate the prevalence of symptoms of white finger and numbing of the upper extremities and to study the possibility that radiological bone changes might

Received 25 October 1982

Accepted 6 December 1982 occur in the wrists of subjects exposed to chain saw vibration.

\section{Subjects}

In a larger project to evaluate the health effects of peat bog dust a total of 298 peat bog workers and 288 forest workers were examined. The group of peat bog workers consisted of $90 \%$ of all the men who were not older than 54 and who worked at preselected peat sites located in six communities in the eastern and western part of Finland. The group of forest workers was selected by matching by age ( \pm 2 years) and domicile. The participation rate was $87 \%$ for the forest workers. In the present study the forest workers formed the group exposed to chain saw vibration and the peat bog workers the reference group.

Since the study concerned the effects of exposure to vibration, forest workers who had used a chain saw for less than one year were excluded. The final group of lumberjacks therefore comprised 279 men with the mean age of 34.6 (SD 9.4) years. The mean 
duration of exposure to vibration was 10.4 (SD 5.8) years, chain saw use averaging 1242 (SD 393.8) hours/year.

Peat bog workers who had used a chain saw for more than a year were discarded from the reference group. The reference group thus included 178 peat bog workers with the mean age of 33.1 (SD 10.2) years. Nineteen of these workers had used a chain saw for one year or less.

\section{Methods}

The subjects were given both a symptom survey and a clinical examination. In the symptom survey the subjects completed a questionnaire that included questions on work history, state of health, medication, symptoms of vibration syndrome, and accidents. An interviewer checked the answers. The clinical examination included laboratory tests on blood and urine, a standard anteroposterior $x$ ray film of both hands and wrists, and a measurement of active movements of the wrists. The examinations were carried out as field studies with the use of a mobile unit.

The prevalence of the white finger symptom was estimated on the basis of the self reported history of finger blanching. The severity of the symptom was graded according to the number of blanching phalanges in the fingers and was classified as mild, moderate, or severe if the number of blanching phalanges was $1-4,5-14$, or $15-28$, respectively.

The radiographs of the hands and wrists were read by two radiologists who did not know whether the radiographs were from the exposed or reference group. All the findings were systematically recorded on precoded sheets. Special attention was paid to bone density, structure, presence of cysts, number and diameter of vacuoles, and posttraumatic and arthrotic changes. Lunate and navicular necrosis was also recorded as were the diameter (1$2 \mathrm{~mm},>2 \mathrm{~mm}$ ) and location of vacuoles.

Wrist movements were measured with a specially constructed apparatus. The hand was placed on a moving indicator and the range of the movements was recorded, the results being read from a graduated scale. The same person made all the measurements.

\section{STATISTICAL METHODS}

In the statistical analyses the chi-square tests with Yates's correction for continuity was used in cases of $2 \times 2$ contingency tables, and the $t$ test was used for testing differences between the means of continuous variables. To analyse the trend in prevalence in relation to age or duration of exposure, $\chi^{2}$-statistics, $\chi_{\text {homog }}^{2}=\chi_{\text {lin }}^{2}+\chi_{\text {slope }}^{2}$, with degrees of freedom $m-1=(m-2)+1$, respectively, were calculated.

The confounding effect of age was controlled in the analysis by stratification, and the MantelHaenszel procedure was used for statistical significance testing. In cases of multiple $2 \times 2$ contingency tables, Mantel's extension of the MantelHaenszel procedure was applied.

\section{Results}

The prevalence of the white finger symptom was $18 \%$ for the lumberjacks and $3 \%$ for the referents $\left(\chi_{(1)}^{2}=20.07, p<0.001\right)$ (table 1). Among the lumberjacks the occurrence of the white finger symptom increased significantly with the duration of exposure to vibration $\left(\chi_{(1)}^{2}=14.58, p<0.001\right)$ and the departure from linearity was not significant $\left(\chi_{2}^{2}=2 \cdot 51, \mathrm{p}>0 \cdot 25\right)$ (table 2$)$. The symptom was not associated with age (table 1 ). When the prevalence of the white finger symptom was estimated on the basis of the number of blanching phalanges, the prevalence was $16 \%$ among the lumberjacks: $2 \%$ had mild, $12 \%$ moderate, and $2 \%$ severe symptoms. The prevalence of moderate or severe symptoms increased linearly with increasing duration of vibration exposure $\left(X_{1}^{2}=10.30, p<0.001 ; \chi_{2}^{2}=3 \cdot 19\right.$, $p>0 \cdot 25)$. Smoking was not associated with this symptom.

Numbing of the wrists was more common among the lumberjacks than among the referents (table 3 ), the prevalences being $51 \%$ and $22 \%$ respectively $\left(X_{1}^{2}=18.51 ; \mathrm{p}<0.001 ;\right.$ Mantel-Haenszel test $)$. The prevalence increased linearly with age in both groups. Numbing severe enough to waken the subject more than one night a week was reported by $17 \%$ of the lumberjacks and $7 \%$ of the referents $\left(X_{1}^{2}\right.$ $=15.21, \mathrm{p}<0.001$; Mantel-Haenszel test). The symptom was not associated with smoking $\left(X_{1}^{2}=0.95\right)$.

The association between numbing of the wrists and duration of exposure to vibration was studied by the application of the Mantel extension of the Mantel-Haenszel procedure. After adjustment for age the association was not significant $\left(X_{1}^{2}=3.44\right.$,

Table 1 Prevalence of the white finger symptom in lumberjacks and referents by age

\begin{tabular}{|c|c|c|c|c|}
\hline \multirow{2}{*}{$\begin{array}{l}\text { Age } \\
\text { (years) }\end{array}$} & \multicolumn{2}{|c|}{ Lumberjacks } & \multicolumn{2}{|l|}{ Referents } \\
\hline & $\begin{array}{l}\text { No of } \\
\text { subjects }\end{array}$ & $\begin{array}{l}\text { Percentage } \\
\text { with symptoms }\end{array}$ & $\begin{array}{l}\text { No of } \\
\text { subjects }\end{array}$ & $\begin{array}{l}\text { Percentage } \\
\text { with symptoms }\end{array}$ \\
\hline $\begin{array}{l}\leqslant 24 \\
25-34 \\
35-44 \\
45-54 \\
\text { Total }\end{array}$ & $\begin{array}{r}41 \\
109 \\
76 \\
53 \\
279\end{array}$ & $\begin{array}{r}5 \\
12 \\
28 \\
26 \\
18\end{array}$ & $\begin{array}{r}48 \\
59 \\
35 \\
36 \\
178\end{array}$ & $\begin{array}{l}2 \\
5 \\
0 \\
6 \\
3\end{array}$ \\
\hline
\end{tabular}


Table 2 Prevalence of the white finger symptom in lumberjacks by duration of exposure to vibration in years

\begin{tabular}{lcc}
\hline $\begin{array}{l}\text { Exposure } \\
\text { (years) }\end{array}$ & $\begin{array}{l}\text { No of } \\
\text { subjects }\end{array}$ & $\begin{array}{l}\text { Percentage } \\
\text { with symptoms }\end{array}$ \\
\hline $1-4$ & 56 & 5 \\
$5-9$ & 73 & 11 \\
$10-14$ & 61 & 21 \\
$15-19$ & 61 & 31 \\
$\geqslant 20$ & 28 & 25 \\
Total & 279 & 18 \\
\hline
\end{tabular}

$\mathrm{p}>0.05)$. An analogous result was obtained with partial correlation analysis.

Among the lumberjacks there was a significant association between the numbing symptom and the white finger symptom $\left(\chi_{1}^{2}=19.02, \mathrm{p}<0.001\right)$ but not among the referents $(p=0 \cdot 106$, Fisher). When the severity of the numbing symptom was graded according to the weekly frequency of waking up at night, the lumberjacks with white finger symptom had higher scores than those without it $(t(277)=3 \cdot 75, \mathrm{p}<0.001)$.

The overall prevalence of cysts in the wrist bones of the lumberjacks was $9 \%$ for each hand. In the reference group the respective prevalences were $8 \%$ and $9 \%$ (table 4 ). The prevalence of bone cysts was higher after the age of 35 in both groups but did not correlate with the duration of exposure to vibration or with the occurrence of the white finger symptom.

Among the lumberjacks three men had lunate necrosis in the right wrist and two navicular necrosis in the left wrist; four of the five had a history of wrist strain. Among the referents there was no lunate or navicular necrosis.

The range of wrist movements among the lumberjacks was somewhat lower than among the referents

Table 3 Prevalence of numbness of upper extremities in lumberjacks and referents by severity and age

\begin{tabular}{|c|c|c|c|c|}
\hline \multirow{2}{*}{$\begin{array}{l}\text { Age } \\
\text { (years) }\end{array}$} & \multirow{2}{*}{$\begin{array}{l}\text { No of } \\
\text { subjects }\end{array}$} & \multirow{2}{*}{$\begin{array}{l}\text { Percentage } \\
\text { experiencing } \\
\text { symptom }\end{array}$} & \multicolumn{2}{|c|}{ Numbness wakes subject } \\
\hline & & & $\begin{array}{l}\text { Once a week } \\
\text { or less }\end{array}$ & $\begin{array}{l}\text { More often } \\
\text { than once a } \\
\text { week }\end{array}$ \\
\hline \multicolumn{5}{|c|}{ Lumberjacks } \\
\hline $\begin{array}{l}\leqslant 24 \\
25-34 \\
35-44 \\
45-54 \\
\text { Total }\end{array}$ & $\begin{array}{r}41 \\
109 \\
76 \\
53 \\
279\end{array}$ & $\begin{array}{r}22 \\
137 \\
169 \\
77 \\
51\end{array}$ & $\begin{array}{l}17 \\
31 \\
37 \\
51 \\
34\end{array}$ & $\begin{array}{r}5 \\
6 \\
32 \\
26 \\
17\end{array}$ \\
\hline $\begin{array}{l}\text { Referent } \\
\leqslant 24 \\
25-34 \\
35-44 \\
45-54 \\
\text { Total }\end{array}$ & $\begin{array}{r}48 \\
59 \\
35 \\
36 \\
178\end{array}$ & $\begin{array}{l}10 \\
15 \\
23 \\
50 \\
22\end{array}$ & $\begin{array}{r}8 \\
8 \\
17 \\
33 \\
15\end{array}$ & $\begin{array}{r}2 \\
7 \\
6 \\
17 \\
7\end{array}$ \\
\hline
\end{tabular}

Table 4 Prevalence of bone cysts in lumberjacks and referents

\begin{tabular}{|c|c|c|c|c|c|c|}
\hline \multirow{2}{*}{$\begin{array}{l}\text { Age } \\
\text { (years) }\end{array}$} & \multirow{2}{*}{$\begin{array}{l}\text { No of } \\
\text { subjects }\end{array}$} & \multicolumn{2}{|c|}{ Lumberjacks } & \multirow{2}{*}{$\begin{array}{l}\text { No of } \\
\text { subjects }\end{array}$} & \multicolumn{2}{|c|}{ Referents } \\
\hline & & $\begin{array}{l}\text { Left } \\
\text { wrist } \\
\text { (\%) }\end{array}$ & $\begin{array}{l}\text { Right } \\
\text { wrist } \\
\text { (\%) }\end{array}$ & & $\begin{array}{l}\text { Left } \\
\text { wrist } \\
\text { (\%) }\end{array}$ & $\begin{array}{l}\text { Right } \\
\text { wrist } \\
\text { (\%) }\end{array}$ \\
\hline $\begin{array}{l}\leqslant 24 \\
25-34 \\
35-44 \\
45-54 \\
\text { Total }\end{array}$ & $\begin{array}{r}41 \\
109 \\
76 \\
53 \\
279\end{array}$ & $\begin{array}{r}5 \\
8 \\
12 \\
8 \\
9\end{array}$ & $\begin{array}{r}5 \\
7 \\
12 \\
13 \\
9\end{array}$ & $\begin{array}{r}48 \\
59 \\
35 \\
36 \\
177\end{array}$ & $\begin{array}{r}2 \\
5 \\
6 \\
22 \\
8\end{array}$ & $\begin{array}{r}4 \\
5 \\
14 \\
17 \\
9\end{array}$ \\
\hline
\end{tabular}

(table 5). The results of the measurements exceeded reference values ${ }^{9}$ in both groups, probably due to improper fixation of the wrist during the measurement.

\section{Discussion}

Since the early 1970 s the prevalence of white finger symptoms induced by vibration among lumberjacks has decreased from $40-50 \%{ }^{15}{ }^{10}$ to $13 \% .^{11}$ The severity of the symptom has also decreased significantly. " The most probable reason for the decrease in the prevalence of the white finger symptom appears to be the damping of chain saw vibration and, also, the reduced weight of the saws. ${ }^{11} 12$ The noise level of the saws has also decreased although the individual noise dose during one working period can be as high as 96-103 $\mathrm{dB}(\mathrm{A}) \mathrm{L}_{\mathrm{eq}}{ }^{12}$

In this study the prevalence of the white finger symptom in the reference group (3\%) was lower than the earlier reported figures of $6-9 \%, 5810$ whereas the corresponding prevalence in the lumberjacks $(18 \%)$ was comparable with the previous study. " The occurrence of this symptom did not

Table 5 Results of measurement of wrist movements

\begin{tabular}{|c|c|c|c|c|}
\hline \multirow[t]{2}{*}{ Movement } & \multicolumn{2}{|c|}{ Lumberjacks } & \multicolumn{2}{|c|}{ Referents } \\
\hline & Mean & $S D$ & Mean & $S D$ \\
\hline $\begin{array}{l}\text { Radial deviation (degrees): } \\
\text { Left wrist } \\
\text { Right wrist }\end{array}$ & $\begin{array}{l}27 \cdot 7^{*} \\
26 \cdot 9^{* *}\end{array}$ & $\begin{array}{l}4 \cdot 4 \\
4 \cdot 7\end{array}$ & $\begin{array}{l}28 \cdot 6 \\
28.4\end{array}$ & $\begin{array}{l}5 \cdot 3 \\
5 \cdot 0\end{array}$ \\
\hline $\begin{array}{l}\text { Ulnar deviation (degrees): } \\
\text { Left wrist } \\
\text { Right wrist }\end{array}$ & $\begin{array}{l}35 \cdot 0^{*} \\
36 \cdot 1\end{array}$ & $\begin{array}{l}5 \cdot 0 \\
1 \cdot 8\end{array}$ & $\begin{array}{l}36 \cdot 2 \\
37 \cdot 2\end{array}$ & $\begin{array}{l}4.9 \\
6.6\end{array}$ \\
\hline $\begin{array}{l}\text { Palmar flexion (degrees): } \\
\text { Left wrist } \\
\text { Right wrist }\end{array}$ & $\begin{array}{l}77 \cdot 0 \\
75 \cdot 5^{*}\end{array}$ & $\begin{array}{l}6 \cdot 6 \\
9 \cdot 3\end{array}$ & $\begin{array}{l}78 \cdot 2 \\
77 \cdot 4\end{array}$ & $\begin{array}{l}6 \cdot 7 \\
7 \cdot 8\end{array}$ \\
\hline $\begin{array}{l}\text { Dorsal flexion (degrees): } \\
\text { Left wrist } \\
\text { Right wrist }\end{array}$ & $\begin{array}{l}64 \cdot 4 \\
63 \cdot 7^{* * *}\end{array}$ & $\begin{array}{l}9 \cdot 0 \\
9 \cdot 0\end{array}$ & $\begin{array}{l}65 \cdot 6 \\
66 \cdot 8\end{array}$ & $\begin{array}{l}7 \cdot 9 \\
8 \cdot 0\end{array}$ \\
\hline
\end{tabular}


increase after the age of 45 , possibly due to selection.

The prevalence of numbing in the upper extremities of lumberjacks was reported to be high in 1972, about $80 \%,{ }^{\prime}$ and long lasting, intense exposure to vibration has been assumed to result in peripheral neuropathy. In an earlier neurophysiological study changes such as slowed maximal conduction velocity of the median and ulnar nerves and lowered conduction velocity of the slower ulnar fibres were reported to occur in $40 \%$ of the forest workers examined..$^{13}$ Neurophysiological changes have also been found among rock drillers. ${ }^{14}$ In the present study the prevalence of numbing was $51 \%$ for the lumberjacks, and the symptom was also common among the referents $(22 \%)$. The prevalence of numbing has not decreased as much as the prevalence of the white finger symptom. Numbness did not correlate with exposure time after adjustment for age, and it may be that the static load and work position could at least partly explain the symptom.

The reports of wrist bone changes (vacuoles, cysts) in different populations exposed to vibration are somewhat controversial. Cysts and vacuoles have been found in $20-26 \%$ of some groups exposed to vibration, ${ }^{2}{ }^{3}$ and aseptic necrosis of the lunate and navicular bones has also been reported among these workers. ${ }^{4}$ These earlier studies were not well controlled, however, and studied groups of workers with intense exposure. Nevertheless, Karjalainen et al found that vibration decreases the blood flow in the saw bearing left hand of lumberjacks and also found the bone mineral density to be lower than in controls of the same age, a finding which could explain the wrist bone vacuoles. ${ }^{15}$ In some other studies, however, differences between exposed and control groups have not been observed. ${ }^{56}$ In our subjects the occurrence of vacuoles was rare, and there was no correlation with the duration of exposure. This result supports the assumption that, nowadays, exposure to chain saw vibration does not predispose to the development of vacuoles in carpal bones.

The differences in wrist movements observed between the lumberjacks and referents of our study were small and clinically insignificant. The measured values exceeded overall reference values for both groups, probably due to some methodological error, but results between the groups are comparable because the same method was used in both groups.

\section{References}

' Pyykkö I, Sairanen E, Korhonen O, Färkkilä M, Hyvärinen J. A decrease in the prevalence and severity of vibration-induced white finger among lumberjacks in Finland. Scand $J$ Work Environ Health 1978;4:246-54.

${ }^{2}$ Kumlin T, Wiikeri M, Sumari P. Radiological changes in carpal and metacarpal bones and phalanges caused by chain saw vibration. Br J Ind Med 1973;30:71-3.

${ }^{3}$ Laitinen J, Puranen J, Vuorinen P. Vibration syndrome in lumbermen. JOM 1974;16:552-6.

4 Horwath F, Kakossy T. Aseptische Nekrosen und Handwurzelknochen von Motorsägearbeitern. Z Orthop 1973;111:90613.

${ }^{5}$ Hellstrøm B, Lange Andersen K. Vibration injuries in Norwegian forest workers. Br J Ind Med 1972;29:255-63.

- James PB, Yates JR, Pearson JCG. An investigation of the prevalence of bone cysts in hands exposed to vibration. In: Taylor $\mathrm{W}$, Pelmear PL, eds. Vibration white finger in industry. London: Academic Press, 1975:43-51.

' Stewart AM, Goda DF. Vibration syndrome. $\mathrm{Br} J$ Ind Med 1970;27:19-27.

8 Taylor W, Pelmear PL, Pearson JCG. Vibration-induced white finger epidemiology. In: Taylor W, Pelmear PL, eds. Vibration white finger in industry. London: Academic Press, 1975:1-13.

9 Committee on rating of mental and physical impairment. Guides to the evaluation of permanent impairment. Chicago: American Medical Association, 1971.

${ }^{10}$ Kylin B, Gerhardsson G, Hansson JE et al. Hälso-och miljöundersökning bland skogsarbetare. Stockholm: Arbetsmedicinska Institutet, 1968. (AI-rapport No 5, 1968.)

" Pyykkö I, Korhonen OS, Färkkilä MA, Starck JP, Aatola SA. A longitudinal study of the vibration syndrome in Finnish forestry workers. In: Brammer AJ, Taylor W, eds. Vibration effects on the hand and arm in industry. New York: John Wiley \& Sons, Inc, 1982: 157-67.

12 Pyykkö I, Starck J, Färkkilä M, Hoikkala M, Korhonen O, Nurminen $M$. Hand-arm vibration in the aetiology of hearing loss in lumberjacks. Br J Ind Med 1981;38:281-9.

${ }^{13}$ Seppäläinen AM. Peripheral neuropathy in forest workers: a field study. Work Environ Health 1972;9:106-11.

14 Chatterjee DS, Barwick DD, Petrie A. Exploratory electromyography in the study of vibration-induced white finger in rock drillers. Br J Ind Med 1982;39:89-97.

is Karjalainen P, Alhava EM, Valtola J. Thenar muscle blood flow and bone mineral in the forearms of lumberjacks. $\mathrm{Br} J$ Ind Med 1975;32:11-5. 